ISSN 1810-3030 (Print) 2408-8684 (Online)

Journal of Bangladesh Agricultural University

Journal home page: http://baures.bau.edu.bd/jbau, www.banglajol.info/index.php/JBAU

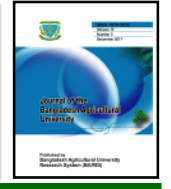

\title{
Determination of toxicity of spinosad against the pulse beetle, Callosobruchus chinensis L.
}

Pronita Mondal, $\bowtie$ Mohammad Mahir Uddin and Mohammad Tofazzal Hossain Howlader

Department of Entomology, Bangladesh Agricultural University, Mymensingh-2202, Bangladesh

\begin{tabular}{|c|c|}
\hline ARTICLE INFO ${ }_{\text {open }}{ }^{\text {access }}$ & Abstract \\
\hline $\begin{array}{l}\text { Article history: } \\
\text { Received: } 12 \text { September } 2018 \\
\text { Accepted: 07 December } 2018 \\
\text { Published: } 31 \text { December } 2018\end{array}$ & \multirow{3}{*}{$\begin{array}{l}\text { Pulses serve as one of the main sources of protein and minerals as well as play a vital socio-economic role } \\
\text { in the diet of common people of Bangladesh but these pulses suffer enormous losses due to infestation of a } \\
\text { serious insect pest pulse beetle, Callosobruchus chinensis } \mathrm{L} \text {. As a part of eco-friendly management of this } \\
\text { detrimental pest, an experiment was conducted at the laboratory to determine the toxicity of spinosad } \\
\text { against the pulse beetle, } C \text {. chinensis L. directly by using dry film contact toxicity method and indirectly } \\
\text { by treating chickpea seeds. In the direct method spinosad showed contact toxicity and the lethal } \\
\text { concentration of spinosad was } 117.46,76.05 \text { and } 37.45 \mathrm{ppm} \text { at } 24,48 \text { and } 72 \text { hours after treatment, } \\
\text { respectively. On the other hand, the } \mathrm{LC}_{50} \text { values were } 990.34,301.35 \text { and } 95.08 \text { ppm after } 24,48 \text { and } 72 \\
\text { HAT, respectively as per indirect method. A dose-dependent relation with the mortality was observed by } \\
\text { both methods. Spinosad was also significantly effective in reducing the number of eggs ( } 68.00 \text { to } 98.60 \% \\
\text { inhibition over control), adult emergence ( } 56.70 \text { to } 100 \% \text { inhibition over control), percent seed infestation } \\
\text { (62.79 to } 100 \% \text { inhibition over control) and seed weight loss ( } 50.81 \text { to } 100 \% \text { inhibition over control). The } \\
\text { present results indicated that spinosad could be suggested for the efficient management of } C \text {. chinensis in } \\
\text { storage. }\end{array}$} \\
\hline chinensis & \\
\hline $\begin{array}{l}\text { Mohammad Mahir Uddin } \\
\text { 凶: mahir@bau.edu.bd }\end{array}$ & \\
\hline
\end{tabular}

(C)2018 by authors and BAURES. This work is licensed under the Creative Commons Attribution International License (CC By 4.0).

\section{Introduction}

Pulse is an important source of protein (approximately 21-25\%) (Tiwari and Shing, 2012). It also provides carbohydrates (50-60\%) and several vitamins and minerals (Chakraborty and Mondal, 2015). A large number of pulses are grown in Bangladesh such as lentil, gram, black gram, grasspea, mungbean, cowpea, etc. and the total production of pulse was 2,03,535 metric tons from the area of 5,57,508 acres in 2007-2008 (BBS, 2009). After harvesting, about $85 \%$ of the pulse growers in Bangladesh store pulses throughout the year in their houses (Ferdowsi, 2013).

Unfortunately, in storage, pulses suffer enormous losses due to bruchid attack, which starts infestation either in the field on the maturing pod and is carried to the stores with the harvested crops or it originates in the storage itself (Fletcher and Ghosh, 2002). Among the different species of pulse beetle, Callosobruchus chinensis L. is the most destructive in Bangladesh which cause losses up to $30 \%$ in a short period of time (Raja and John, 2008). The post-harvest seed losses due to the beetle can reach even up to $100 \%$ during severe infestation (Srinivasan et al., 2010).

During storage for grain protection, liquid insecticides and gases in the form of phosphine and methyl bromide have been widely used and Bangladeshi farmers are also using this synthetic chemical insecticides and fumigants (Matin, 2003). However, their application is being discouraged globally due to many problems such as resistance, residue problems. A tendency to use safe and low toxicity insecticides has been increased (Odeyemi $e t$ al., 2006; Sadeghi et al., 2006).

In recent years, spinosad is a safe biopesticide derived from naturally occurring soil actinomycete, Saccharopolyspora spinosa Mertz and Yao (Bacteria: Actinobacteridae) (Sparks et al., 1998). Spinosad for its limited non-target and chronic effects, in 1993, spinosad was labeled as a "reduced risk" compound by the EPA and in 2005, the EPA registered spinosad at $1 \mathrm{mg} / \mathrm{kg}$ active substance (a.s.) as a grain protectant on commodities including wheat, corn, rice, millets, oats, sorghum and barley (Huang and Subramanyam, 2007). It is toxic to insects by ingestion or contact and it acts on an insect's nervous system at the nicotinic acetylcholine and gamma-aminobutyric acid (GABA) receptor sites (Salgado and Sparks, 2005; Osorio et al., 2008). The test insect dies within 1 to 2 days after ingesting the active ingredient.

It has been found to be effective against stored pests (Hertlein et al., 2011). It is predicted that the Spinosad will be used more widely in many countries for the management of storage pests (Vayias et al., 2009). In Bangladesh, spinosad has already been registered for use on cotton, jute, rice against Lepidopteran pests. Information on effects of spinosad against the pulse beetle is very limited in Bangladesh. So, considering the 
above situations, the present research was conducted to determine the toxicity of spinosad against the pulse beetle, $C$. chinensis under laboratory condition.

\section{Materials and Methods}

The experiment was conducted at the laboratory of Department of Entomology, Bangladesh Agricultural University (BAU), Mymensingh during March 2015 to May 2016. The experiment was laid out in Completely Randomized Design (CRD) having four treatments. Fresh and disease free chickpea (Cicer arietinum L.) seeds were used as host for the pulse beetles and purchased from the local ' $\mathrm{K} \& \mathrm{R}$ Market' of BAU campus, Mymensingh. Pulse beetle, C. chinensis L. was used as test insect in this study. The insects were collected from a stock culture of the Entomology Department, BAU as well as from Entomology Division of Bangladesh Institute of Nuclear Agriculture (BINA) and then reared in the laboratory as per the following protocol. The average temperature and relative humidity during the study were $27 \pm 3^{\circ} \mathrm{C}$ and $72 \pm 3 \%$, respectively.

Pulse beetle was mass reared in glass jar and in plastic box also. Approximately 100 adults of the insect were released in each box containing $500 \mathrm{~g}$ of chickpea seeds and the mouth being closed with fine mesh net for proper ventilation. The beetles were allowed for free mating followed by oviposition for a maximum period of 10 days. After oviposition, the beetles were separated from the seeds through sieving and seeds along with eggs were left in the containers to maintain a stock culture of the test insect. The stock culture of test insect was maintained throughout the experimental period and this process was repeated regularly to get sufficient number of adult beetles for conducting the experiments.

In this experiment, the toxicity of spinosad was evaluated through bioassay procedure. A serial dilution of the formulated Spinosad was prepared and toxicity was determined against $C$. chinensis. Different concentrations of Spinosad were considered as experimental treatment. To prepare them, at first $100 \mathrm{ml}$ $10,000 \mathrm{ppm}$ of spinosad was prepared as first stock solution by adding $2.22 \mathrm{ml}$ spinosad with $97.78 \mathrm{ml}$ distilled water. Then, $100 \mathrm{ml} 1000 \mathrm{ppm}$ of spinosad as second stock solution $\left(10.00 \mathrm{ml}\right.$ from $1^{\text {st }}$ stock solution $+90.00 \mathrm{ml} \mathrm{dH}_{2} \mathrm{O}$ ) was prepared. Then the experimental treatments were prepared by taking required amount from second stock solution for each experiment as shown below.

Table 1. Preparation of Spinosad serial dilutions

\begin{tabular}{cccc}
\hline Treatments & $\begin{array}{c}\text { Concentration } \\
\left.\text { (in ppm }^{*}\right)\end{array}$ & $\begin{array}{c}\text { Amount of spinosad } \\
(\mathrm{ml} / 10 \mathrm{ml} \text { in distilled } \\
\text { water })\end{array}$ & $\begin{array}{c}\text { Amount of } \\
\text { distilled } \\
\text { water }\end{array}$ \\
\hline $\mathrm{T}_{1}$ & 0 & 0 & 10 \\
$\mathrm{~T}_{2}$ & 30 & 0.3 & 9.7 \\
$\mathrm{~T}_{3}$ & 50 & 0.5 & 9.5 \\
$\mathrm{~T}_{4}$ & 100 & 1 & 9.0 \\
$\mathrm{~T}_{5}$ & 150 & 1.5 & 8.5 \\
$\mathrm{~T}_{6}$ & 200 & 2 & 8.0 \\
$\mathrm{~T}_{7}$ & 500 & 5 & 5.5 \\
\hline
\end{tabular}

(*ppm= parts per million)

For direct toxicity assay of spinosad dry film contact method described by Sadat and Asghar (2006) was used to determine the toxicity of spinosad to adults of pulse beetle, $C$. chinensis under laboratory conditions. Bioassays were performed on filter paper placed inside Petri-dishes (90 mm x $14 \mathrm{~mm}$, diameter x height). The required dilutions were prepared from the commercial formulation of spinosad with distilled water described earlier. For control treatment, filter paper was soaked only in distilled water. Seven concentrations including one control were used for the bioassay test. Initially, filter paper disks on both sides of the Petri-dishes fitted with yellow tape and then they were treated with $2 \mathrm{ml}$ each of different concentrations of spinosad solutions along with control placed in the bottom and the lid of 90-mm Petri-dishes and allowed to dry. After drying of the Petri-dishes, 15 newly emerged adults of $C$. chinensis were separated from cultures and introduced into each dish of different concentrations and control. The experiment was replicated for four times.

Insect mortality data were recorded at 24, 48 and $72 \mathrm{hrs}$ of post release. Insects that were immobile or unable to move were considered as dead insect. The percent mortality was determined as per following formula:

Percent mortality $=\frac{\text { No.of dead pulse beetle }}{\text { Total no.of released pulse beetle }} \times 100$

To determine corrected mortality Abbott's formula was used and $\mathrm{LC}_{50}$ values were calculated by probit analysis.

Abbott's formula, $P=\frac{p^{\prime}-C}{100-C} \times 100$

Where,

$\mathrm{P}=$ the corrected mortality $(\%)$

$\mathrm{P}^{\prime}=$ the observed mortality (\%)

$\mathrm{C}=$ the control mortality

Abbott's formula, $\mathrm{P}_{\text {corr }}=\frac{\text { Pexp }- \text { Pcont }}{1-\text { Pcont }}$

Where,

$\mathrm{P}_{\text {corr }}=$ Mean experimental treatment response corrected for control response

$P_{\text {exp }}=$ Mean experimental treatment response

$P_{\text {cont }}=$ Mean control response

Toxicity of spinosad was also tested indirectly against the pulse beetle, $C$. chinensis indirectly by treating the pulses and thereafter evaluating toxicity against the insect. In order to do that five concentrations and a control with three replications were tested. The five serial diluted concentrations $(50,100,200,500$ and 1000 $\mathrm{ppm})$ of spinosad were prepared following same protocols mentioned earlier. To assess the toxicity, $50 \mathrm{~g}$ of chickpea seeds was taken in each Petri-dish and treated with one milliliter of prepared diluted concentration of spinosad for each treatment and mixed thoroughly by shaking. The treated seeds were then kept for few minutes for drying. Five pairs of newly emerged 
adults of $C$. chinensis were released in each Petri-dish and kept in room temperature for recording of data.

Mortality data were recorded at 24, 48 and $72 \mathrm{hrs}$ of post release from each Petri-dish. The percent mortality was determined as per the formula mentioned earlier. Number of eggs laid by the released beetles, termed as rate of oviposition was recorded after 10 days of post release. The emerged $C$. chinensis adults were counted daily from the beginning of the first insect emergence started at 20 days after post insect release and continued up to 3 weeks. The data was recorded at 25 and 45 days after insect release (DAIR). Then the percent seed infestation was calculated according to the following formula stated by Enobakhare and Law-Ogbomo (2002).

Percent grain damage $=\frac{\text { Number of bored seeds }}{\text { Total no. of seeds observed }} \times 100$

Data recorded at 45 DAIR and then the percent weight loss was measured using the following formula as stated by Lal (1988).

Percent weight loss $=$

$$
\frac{\text { Weight loss seed grains per Petri - dish }}{\text { Initial weight of seed grains per Petri - dish }} \times 100
$$

Weight loss per Petri-dish $=$ (Initial weight- final weight) of grains per Petri-dish.

The inhibition of oviposition rate, adult emergence, seed infestation and seed weight loss was computed by using the following formula as stated by Shukla et al. (2007).

Percent inhibition $=\frac{\text { Control mean }- \text { Treatent mean }}{\text { Control mean }} \times 100$

The mortality data were corrected by using Abott's formula (Abbott, 1925) and the $\mathrm{LC}_{50}$ values were calculated by probit analysis (Finney, 1971). All other collected data were analyzed in Completely Randomized Design (CRD) by using Analysis of Variance (ANOVA). The treatment mean values of different parameters were separated by using the Duncan's Multiple Range Test (DMRT) (Duncan, 1951) and Least Significant Difference (LSD). Data analysis was carried out using the computer package MSTAT-C and graphical works through Microsoft Excel program in a computer.

\section{Results and Discussion}

Direct toxicity of spinosad against pulse beetle, $C$. chinensis

The direct toxicity of spinosad against the adults of $C$. chinensis at different hours after treatment (HAT) using seven different concentrations viz., 0, 30, 50, 100, 150, 200 and 500 ppm was tested and results showed that the mortality rates of $C$. chinensis increased proportionately with the increase of spinosad concentration and exposure time. The percent corrected mortality of $C$. chinensis with different concentrations of spinosad was 28.30, 43.40, 49.06, 52.83, 58.49 and 66.04 at 24 HAT and $34.04,38.30,59.58,63.83,65.96$ and 78.72 at 48 HAT for $30,50,100,150,200$ and 500 ppm of spinosad, respectively. At 72 HAT, $100.00 \%$ insects were died at 500 ppm concentration whereas at 30, 50, 100, 150, 200 ppm, the percent corrected mortality was $42.50,57.50$, $77.50,82.50$ and 82.50 , respectively at the same time (Fig. 1). It was observed that higher percent mortality occurred at higher concentration of spinosad and viceversa, i.e., in a dose-dependent relation. Spinosad may cause $100 \%$ mortality at 24 HAT (Vishwamithra et al., 2014). Similar results were also reported by Duraimurugan et al. (2014) and Sadat and Asghar (2006). The present findings are supported by these results.

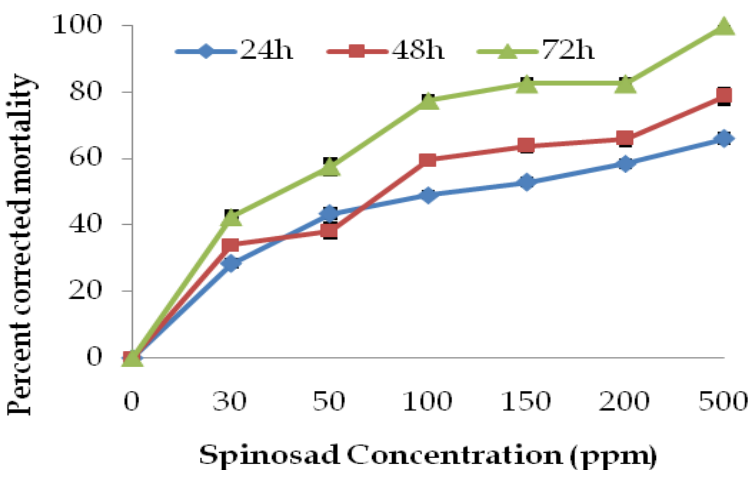

Fig. 1. Toxicity of spinosad against pulse beetle, $C$. chinensis determined by direct film method

The $\mathrm{LC}_{50}$ values of spinosad to $C$. chinensis were 117.46, 76.05 and 37.45 ppm after 24, 48 and 72 HAT, respectively. It was indicated that lower the time higher amount of spinosad was required and vice-versa. Other lethal concentrations values followed the same trend (Table 2). Duraimurugan et al. (2014) observed that $\mathrm{LC}_{50}$ values of spinosad at 24, 48 and 72 hours posttreatment were 51.05, 11.99 and 1.92 ppm, respectively against $C$. chinensis. Similar toxic effect of spinosad was also reported by various authors (Abd El-Razik and Zayed, 2014; Abouelghar et al., 2013; Hameed et al., 2012; Sadat and Asghar, 2006 and Hussain et al., 2005). The findings of the present research work are almost similar with the previous reports.

\section{Indirect toxicity of spinosad against pulse beetle, $C$. chinensis}

Similar to direct film method, it was found that mortality of pulse beetle increased proportionately with the increase of spinosad and exposure time. The percent corrected mortality of $C$. chinensis was 3.85, 23.08, $30.77,38.46$ and 46.15 at 24 HAT; and at 48 HAT, it was $29.17,33.33,41.67,58.33$ and 66.67 for 50, 100, 200, 500 and 1000 ppm of spinosad, respectively. At 72 HAT the highest mortality $(88.89 \%)$ was found at 1000 ppm concentration (Fig. 2). The $\mathrm{LC}_{50}$ values of spinosad to $C$. chinensis were $990.34,301.35$ and 95.08 ppm after 24, 48 and 72 HAT, respectively (Table 3). Comparing to direct method, it was found that higher amount of spinosad were required when applied indirectly might be due to repellent effect. 
The present study revealed the reduction of insect population was due to the use of spinosad and also agreed with the previous findings of Khashaveh et al. (2011) where they stated that the mortality of exposed individuals in treated commodities was low at 1-day exposure even at $0.3 \mathrm{~g} / \mathrm{kg}$ and did not exceed $20 \%$ and mortality increased with the increase of exposure interval and doses. Rajput et al. (2013), Mirmoayedi et al. (2011) and Hussain et al. (2009) reported similar kind of observations.

Table 2. Toxicity of spinosad against pulse beetle, $C$. chinensis at 24, 48, 72 HAT by direct film method

\begin{tabular}{|c|c|c|c|c|c|c|}
\hline \multirow[t]{2}{*}{$\begin{array}{l}\text { Time } \\
\text { (hr) }\end{array}$} & \multirow[t]{2}{*}{$\begin{array}{c}\text { No. of insects } \\
\text { tested }\end{array}$} & \multirow[t]{2}{*}{ Slope \pm SE } & \multirow[t]{2}{*}{$\chi^{2}$} & \multicolumn{3}{|c|}{$\begin{array}{l}\text { Lethal Concentration (ppm) } \\
\text { (Fiducial Limit) }\end{array}$} \\
\hline & & & & $\mathrm{LC}_{25}$ & $\mathrm{LC}_{50}$ & $\mathrm{LC}_{90}$ \\
\hline 24 & 60 & $0.75 \pm 0.17$ & 1.26 & $\begin{array}{c}14.80 \\
(2.59-30.35)\end{array}$ & $\begin{array}{c}117.46 \\
(75.23-185.87)\end{array}$ & $\begin{array}{c}6016.08 \\
(1688.03-156163.37)\end{array}$ \\
\hline 48 & 60 & $1.04 \pm 0.18$ & 1.15 & $\begin{array}{c}17.02 \\
(6.23-29.03)\end{array}$ & $\begin{array}{c}76.05 \\
(51.54-102.51)\end{array}$ & $\begin{array}{c}1307.30 \\
(663.88-4851.62)\end{array}$ \\
\hline 72 & 60 & $1.47 \pm 0.26$ & 1.18 & $\begin{array}{c}13.05 \\
(4.87-21.54)\end{array}$ & $\begin{array}{c}37.45 \\
(23.19-49.73)\end{array}$ & $\begin{array}{c}277.73 \\
(187.60-583.87)\end{array}$ \\
\hline
\end{tabular}

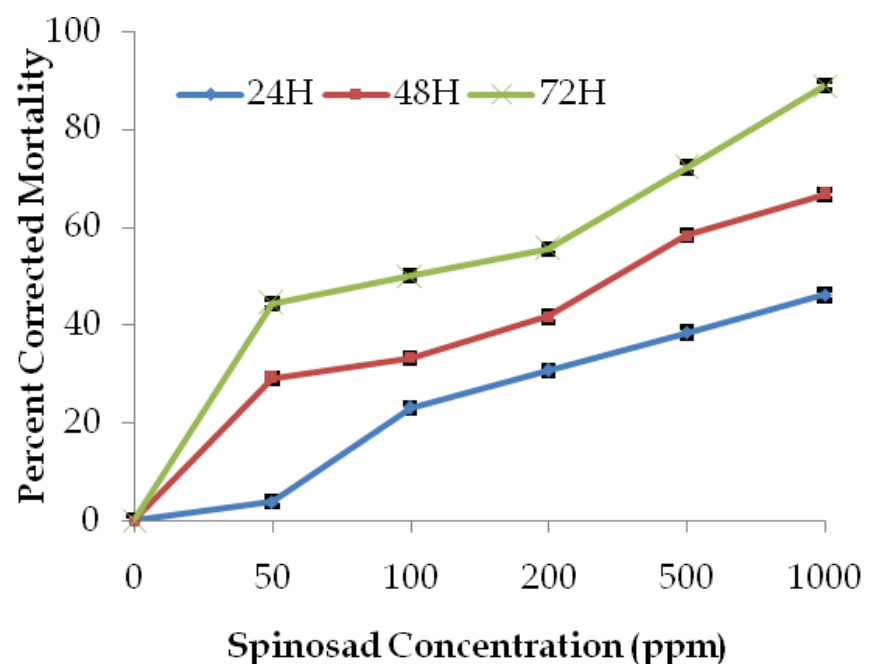

Fig. 2. Toxicity of spinosad against pulse beetle, $C$. chinensis determined by indirect application method

Table 3. Toxicity of spinosad against pulse beetle, $C$. chinensis at 24, 48, 72 HAT by indirect method

\begin{tabular}{|c|c|c|c|c|c|c|}
\hline \multirow[t]{2}{*}{$\begin{array}{l}\text { Time } \\
\text { (hr) }\end{array}$} & \multirow[t]{2}{*}{$\begin{array}{c}\text { No. of insects } \\
\text { tested }\end{array}$} & \multirow[t]{2}{*}{ Slope \pm SE } & \multirow[t]{2}{*}{$\chi^{2}$} & \multicolumn{3}{|c|}{$\begin{array}{l}\text { Lethal Concentration (ppm) } \\
\text { (Fiducial Limit) }\end{array}$} \\
\hline & & & & $\mathrm{LC}_{25}$ & $\mathrm{LC}_{50}$ & $\mathrm{LC}_{90}$ \\
\hline 24 & 60 & $0.96 \pm 0.25$ & 2.94 & $\begin{array}{c}195.45 \\
(90.12-337.18)\end{array}$ & $\begin{array}{c}990.34 \\
(525.89-4679.24)\end{array}$ & $\begin{array}{c}21620.69 \\
(4609.20-2256880.84)\end{array}$ \\
\hline 48 & 60 & $0.80 \pm 0.23$ & 0.25 & $\begin{array}{c}42.73 \\
(4.20-92.95)\end{array}$ & $\begin{array}{c}301.35 \\
(161.19-739.23)\end{array}$ & $\begin{array}{c}12331.18 \\
(2695.42-2325034.11)\end{array}$ \\
\hline 72 & 60 & $0.96 \pm 0.24$ & 1.67 & $\begin{array}{c}18.76 \\
(1.80-45.08)\end{array}$ & $\begin{array}{c}95.08 \\
(36.19-159.69)\end{array}$ & $\begin{array}{c}2076.01 \\
(854.59-22444.10)\end{array}$ \\
\hline
\end{tabular}

Effect of spinosad on oviposition, adult emergence, seed infestation $(\%)$, seed weight loss $(\%)$ and inhibition rate $(\%)$ of $C$. chinensis

\section{Effect on oviposition rate of $C$. chinensis}

The mean number of eggs laid by $C$. chinensis on chickpea seeds in different treatments ranged from 2.33 to 166.67 per 250 seeds and differed significantly $(p \leq 0.01)$. Among the treatments, the highest number of eggs (166.67) was laid in control and the lowest number of eggs (2.33) was deposited on the seeds treated with
$1000 \mathrm{ppm}$ of spinosad. The number of eggs at 100, 200 and 500 ppm concentration were 26.33, 17.00, and 8.33, respectively (Table 4). The inhibition of oviposition rate was increased from 68 to $98.60 \%$. The highest inhibition on oviposition rate of $C$. chinensis was recorded when seeds were treated with 1000 ppm spinosad (Table 4). The findings on the oviposition of the present study is similar with the report of Vishwamithra et al. (2014) who found $28.67 \mathrm{eggs}$ per $30 \mathrm{~g}$ seed where they treated the seeds with spinosad 45SC @ 4ppm/kg seed. These findings derive support from who found. 
Table 4. Toxic effect of spinosad on oviposition, adult emergence, seed infestation (\%), seed weight loss (\%) and inhibition rate $(\%)$ of $C$. chinensis

\begin{tabular}{|c|c|c|c|c|c|c|c|c|c|}
\hline Dose (ppm) & $\begin{array}{c}\text { Number of } \\
\text { eggs/ } 250 \\
\text { seeds }\end{array}$ & $\begin{array}{l}\text { Inhibition } \\
\text { rate } \\
(\%)\end{array}$ & $\begin{array}{c}\text { Number of adults } \\
\text { emerged } / 250 \\
\text { seeds }\end{array}$ & $\begin{array}{l}\text { Inhibition } \\
\text { rate } \\
(\%)\end{array}$ & $\begin{array}{c}\text { Seed } \\
\text { infestation }(\%) \\
\text { at } 25 \text { DAIR }^{*}\end{array}$ & $\begin{array}{c}\text { Seed } \\
\text { infestation }(\%) \\
\text { at } 45 \text { DAIR }\end{array}$ & $\begin{array}{c}\text { Inhibition } \\
\text { rate }(\%)\end{array}$ & $\begin{array}{c}\text { Seed weight } \\
\text { loss }(\%) \text { at } \\
45 \text { DAIR }\end{array}$ & $\begin{array}{l}\text { Inhibition } \\
\text { rate } \\
(\%)\end{array}$ \\
\hline Control & $166.67 \mathrm{a}$ & - & $87.00 \mathrm{a}$ & - & $9.33 \mathrm{a}$ & $57.33 a$ & - & $4.33 a$ & - \\
\hline 50 & $53.33 b$ & 68.00 & $37.67 \mathrm{~b}$ & 56.70 & $0.40 \mathrm{~b}$ & $21.33 b$ & 62.79 & $2.13 b$ & 50.81 \\
\hline 100 & $26.33 \mathrm{c}$ & 84.20 & $16.67 \mathrm{c}$ & 80.84 & $0.23 \mathrm{~b}$ & $10.27 \mathrm{c}$ & 82.09 & $0.90 \mathrm{c}$ & 79.21 \\
\hline 200 & $17.00 \mathrm{~d}$ & 89.80 & $8.67 d$ & 90.04 & $0.10 \mathrm{~b}$ & $4.93 \mathrm{~d}$ & 91.40 & $0.30 \mathrm{~d}$ & 93.07 \\
\hline 500 & $8.33 \mathrm{e}$ & 95.00 & $2.67 \mathrm{e}$ & 96.93 & $0.0 \mathrm{~b}$ & $1.17 \mathrm{e}$ & 97.96 & $0.17 \mathrm{de}$ & 96.07 \\
\hline 1000 & $2.33 f$ & 98.60 & $0.00 \mathrm{e}$ & 100 & $0.0 \mathrm{~b}$ & $0.00 \mathrm{~d}$ & 100 & $0.00 \mathrm{e}$ & 100 \\
\hline LSD value & 4.953 & - & 5.125 & - & 0.6504 & 3.018 & - & 0.1764 & - \\
\hline $\begin{array}{c}\text { Level of } \\
\text { Significance }\end{array}$ & 0.01 & - & 0.01 & - & 0.01 & 0.01 & - & 0.01 & - \\
\hline $\mathrm{CV}(\%)$ & 8.08 & - & 4.35 & - & 15.52 & 7.64 & - & 5.42 & - \\
\hline
\end{tabular}

$* \mathrm{DAIR}=$ Days after insect release, Different letters in a column differ significantly, $\mathrm{p} \leq 0.01$

\section{Effect on adult emergence of $C$. chinensis}

The mean number of adults of $C$. chinensis emerged from the chickpea seeds ranged from 0.0 to 87.00 which differed significantly $(\mathrm{p} \leq 0.01)$. Significantly the highest number of adult was emerged from control (87.00) and no adult was emerged from the chickpea seeds treated with $1000 \mathrm{ppm}$ of spinosad which was statistically similar to $500 \mathrm{ppm}$ spinosad (2.67). When the inhibition rate of adult emergence over control was compared, it showed the same trend as observed for oviposition rate (Table 4) which coincided with Vishwamithra et al., (2014) study who found $8.55 \%$ adult emergence in seeds treated with Spinosad (4ppm/kg seed) and also parallel with Adel khashaveh et al. (2011) where they reported that the application of spinosad significantly reduced progeny production.

\section{Effect of spinosad on seed infestation (\%)}

The effect of spinosad on seed damage due to feeding by C. chinensis is presented in Table 4. At 25 DAIR infestation was negligible in treated seeds but in untreated seeds $9.33 \%$ infestation was recorded. Statistically similar results were observed from the treatments.

On the other hand, with the increase of time seed damage increased and it differed significantly $(\mathrm{p} \leq 0.01)$ at 45 DAIR among the treatments and the rate varied from 0.00 to $57.33 \%$. At 45 DAIR, the highest seed infestation was recorded in control $(57.33 \%)$. No seed infestation was recorded when seeds were treated with $1000 \mathrm{ppm}$ of spinosad resulting in maximum inhibition rate $(100.00 \%)$ (Table 4). The present research is supported by Sanon et al. (2010) observed that less than $20 \%$ of the seeds were perforated in the spinosad treatment and controlled $C$. maculatus throughout the 6 months of cowpea storage. Bonjour et al. (2006), Islam et al. (2007) and Athanassiou et al. (2008) reported similar effects of spinosad.

Seed weight loss (\%) caused by $C$. chinensis

Seed weight loss was caused as a result of the feeding by the larvae of pulse beetle. Significant variation $(p \leq 0.01)$ in terms of weight loss was also observed among the chickpea seeds treated with spinosad after 45 DAIR. The weight loss of seed in different treatments including the control ranged from 0.00 to $4.33 \%$. The highest seed weight loss was recorded in control (4.33\%) and no seed weight loss was recorded when seeds were treated with $1000 \mathrm{ppm}$ of spinosad (0.00) which was statistically almost similar to $500 \mathrm{ppm}(0.17)$ of spinosad. The inhibition rate followed the similar trend as observed for oviposition and adult emergence. The result is as well concurring with the studies made by Subramanyam et al. (2003), Sadat and Asghar (2006), Vayias et al. (2009) and Hertlein et al. (2011) who reported the toxicity of spinosad to coleopteran stored-grain pests.

\section{Conclusion}

In case of direct toxicity assay through dry film contact method it was found that spinosad possessed significant contact toxicity against $C$. chinensis. The corrected mortality rate increased proportionately with the increase of spinosad concentration and exposure time. Comparing to direct method, these values were higher in indirect method might be due to the repellent effect. The results revealed that the biopesticide was effective in reducing the number of eggs, number of adults emerged, seed infestation and seed weight loss over control. From the results of the present investigation, it could be concluded that toxicity of spinosad was increased significantly with the increasing doses and duration of exposure. Therefore, spinosad might be an alternative, safe and eco-friendly tactic for the management of pulse beetle in the storage.

\section{References}

Abbott, W.S. 1925. A method of computing the effectiveness of an insecticide. Journal of Economic Entomology. 18: 256267. https://doi.org/10.1093/jee/18.2.265a

Abd El-Razik, M.A.A. and Zayed, G.M.M. 2014. Effectiveness of three plant oils in binary mixtures with pyridalyl, abamectin, spinosad and malathion against Callosobruchus maculatus (F.) adults. American Journal of Biochemistry and Molecular Biology. 4: 76-85. https://doi.org/10.3923/ajbmb.2014.76.85

Abouelghar, G.E., Sakr, H., Amaar, H.A., Yousef, A. and Nassar, M. 2013. Sublethal effects of spinosad (tracer®) on the cotton leafworm (Lepidoptera: Noctuidae). Journal of Plant Protection Research 53(3): 275284. 
BBS. 2009. Statistical Yearbook of Bangladesh. Bangladesh Bureau of Statistics. Ministry of Planning, Dhaka.

Bonjour, E.L., Phillips, T.W. and Pitts, J.T. 2006. Spinosad provides long-term protection for stored wheat. 9th International Working Conference on Stored Product Protection. pp. 1189-1193.

Chakraborty, S. and Mondal, P. 2015. Studies on the biology of pulse beetle (Callosobruchus chinensis L.) infesting cowpea. International Journal of Current Research 7(12): 2351223515.

Duncun, D.B. 1951. A significance test for differences between ranked treatments in an analysis of variance. Virginia Journal of Science 2: 171189.

Duraimurugan, P., Mishra, A., Pratap, A. and Singh, S.K. 2014. Toxicity of spinosad to the pulse beetle, Callosobruchus chinensis (Coleoptera: Bruchidae) and its parasitoid, Dinarmus basalis (Hymenoptera: Pteromalidae). The Ecoscan 8(1 \& 2): 1721.

Enobakhare, D.A. and Law-Ogbomo, K.E. 2002. Reduction of postharvest loss caused by Sitophillus zeamays (Motsch) in three varieties of maize treated with plant products. Postharvest Science 1: 116

Ferdowsi, S. 2013. Effect of some plant extracts on egg laying, incubation and adult emergence of pulse beetle and protection of mungbean seeds in storage. MS Thesis, Department of Entomology, Sher-E-Bangla Agricultural University, Dhaka-1207, 61 p.

Finney, D.J. 1971. Probit Analysis. 3rd Edition. Cambridge Univeristy Press, Cambridge, UK. p. 333.

Fletcher, T.B. and Ghosh, C.C. 2002. Stored grain pests. Rep. Proc. 3rd Ent. Meeting, Pusa, New Delhi. pp. 712-716.

Hameed, A., Freed, S., Hussain, A., Iqbal, M.M., Hussain, M., Naeem, M., Sajjad, A., Hussnain, H., Sadiq, M.A. and Tipu, A.L. 2012. Toxicological effects of neem (Azadirachta indica), Kanair (Nerium oleander) and spinosad (Tracer 240SC) on the red flour beetle (Tribolium castaneum) (Herbst.) African Journal of Agricultural Research 7(4): 555560.

Hertlein, M.B., Thompson, G.D., Subramanyam, B. and Athanassiou, C.G. 2011. Spinosad: a new natural product for stored grain protection. Journal of Stored Products Research 47: 131146.

Huang, F., Subramanyam, B. and Hou, X. 2007. Efficacy of spinosad against eight stored-product insect species on hard white winter wheat. Biopesticides International 3(2): 117-125.

Hussain, R., Ashfaq, M. and Saleem, M.A. 2009. Biochemical abnormalities produced by spinosad in Tribolium castaneum adult beetles. International Journal of Agriculture and Biology 11(3): 241-244.

Hussain, R., Ashfaq, M., Saleem, M.A. and Ahmed, S. 2005. Toxicity of some insecticides with novel modes of action against malathion-resistant and organophosphate susceptible strains of Tribolium castaneum larvae. International Journal of Agriculture and Biology 7(5): 768-772.

Islam, M.S., Akhter, F., Laz, R. and Parween, P. 2007. Oviposition preference of Callosobruchus maculatus (F.) to common pulses and potentiality of triflumuron as their protectant. Journal of Bio- Science 15: 8388.

Khashaveh, A., Ziaee, M. and Safaralizadeh, M.H. 2011. Control of pulse beetle, Callosubruchus maculatus (F.) (Coleoptera: Bruchidae) in different cereals using spinosad dust in storage conditions. Journal of Plant Protection Ressearch 51(1): 7781.

Lal, S. 1988. Estimation of losses and economics of specific storage losses. Regional Workshop on On-Farm Storage Facilities and Design, Harpur, India. pp. 79-89.

Matin, M.A. 2003. Pesticides in Bangladesh. In Taylor, M.D., Klaine, S.J. Carvalho, F.P., Barcelo, D., and Everaarts, J., (Eds.) Pesticide Residues in Coastal Tropical Ecosystems: Distribution, Fate and Effects. London: Taylor and Francis Group, P. 137-158. PMCid:PMC1782961

Mirmoayedi, A., Zamani, A.A. and Kasrayie, N. 2011. Effect of spinosad towards insect pests of stored products, Lasioderma serricorne F. and Tribolium confusum Du Val. Pesticide Research Journal 23(1): 111113.
Odeyemi, O., Gbaye, O. and Akeju, O. 2006. Resistance of Callosobruchus maculatus (Fab.) to pirimiphos methyl in three zones in Nigeria. pp. 324-329. In: Proc. 9th International Working Conference on Stored Products Protection, Campinas, Sauo Paulo, Brazil. 15-18 October, 2006. p. 1355.

Osorio, A., Martinez, A.M., Schneider, M.I., Diaz, O., Corrales, J.L., Aviles, M.C., Smagghe, G. and Pineda, S. 2008. Monitoring of beet armyworm resistance to spinosad and methoxyfenozide in Mexico. Pest Management Science 64: 10011007.

Raja, M. and John, S. 2008. Impact of volatile oils of plants against the cowpea beetle, Callosobruchus maculatus (FAB.) (Coleoptera: Bruchidae). International Journal of Integrative Biology 2(1): 62-64.

Rajput, R.B., Patil, R.H. and Awaknavar, J.S. 2013. Efficacy of new insecticide seed protectants against major storage insect pests of wheat and cowpea. Karnataka Journal of Agricultural Sciences 26(3): 372374.

Sadat, K.M. and Asghar, P.A. 2006. The influence of post-exposure temperature on the toxicity of spinosad against adults of Callosobruchus maculatus Fab. (Coleopera: Bruchidae). In: Proceedings of the 9th International Working Conference for Stored-Product Protection. Campinas, Sao Paulo, Brazil. pp. 258-262.

Sadeghi, A., Damme, V.E., Peumans, W. and Smagghe, G. 2006. Deterrent activity of plant lectins on cowpea weevil, Callosobruchus maculatus (F.) oviposition. Photochemistry 67(18): 2078-2084. https://doi.org/10.1016/j.phytochem.2006.06.032 PMid:16887156

Salgado, V.L. and Sparks, T.C. 2005. The spinosyns: chemistry, biochemistry, mode of action and resistance. In: Gilbert L.J., Latrou, K., Gill, S.S. (eds.), Comprehensive Molecular Insect Science. Elsevier, Oxford. pp. 137173. https://doi.org/10.1016/B0-44-451924-6/00078-8

Sanon, A., Niango, M.B., Clementine, L., Binso-Dabire and Pittendrigh, B.R. 2010. Effectiveness of spinosad (naturalytes) in controlling the cowpea storage pest, Callosobruchus maculatus (Coleoptera: Bruchidae). Journal of Economic Entomology 103(1): 203210.

Sharma, S.S. 1984. Review of literature of the losses caused by Callosobruchus chinensis (L.) (Coleoptera: Bruchidae) during storage of pulses. Bulletin of Grain Technology 22(1): 6268 .

Shukla, R., Srivastava, B., Kumar, R. and Dubey, N.K. 2007. Potential of some botanical powders in reducing infestation of chickpea by Callosobruchus chinensis (L.) (Coleoptera: Bruchidae). Journal of Agriculture and Technology 3(1): 1119.

Sparks, T.C., Thompson, G.D., Kirst, A., Hertlein, B., Larson, L., Worden, V. and Thibault, T. 1998. Biological activity of spinosyns, new fermentation derived insect control agents, on tobacco budworm (Lepidoptera: Noctuidae) larvae. Journal of Economic Entomology 91: 12771283.

Srinivasan, T., Duraimurugan, P., Singh, S.K. and Chattopadhyay, C. 2010. Bruchids infestation in pulses and its management. Indian Farming. 60: 1316.

Subramanyam, B., Toews, M. and Fang, L. 2002. Spinosad: An effective replacement for organophosphate grain protectants; Advances in stored product protection

Thompson, G.D., Dutton, R. and Sparks, T.C. 2000. Spinosad- a case study: An example from a natural products discovery programme. Pest Management Science 56: 696702.

Tiwari B.K., Singh N. 2012. Pulse chemistry and technology. Royal Society of Chemistry, Cambridge, Royal Society of Chemistry, 310p.

Vayias, B.J., Athanassiou, C.G. and Buchelos, C.T. 2009. Effectiveness of spinosad combined with diatomaceous earth against different European strains of Tribolium confusum Du Val (Coleoptera: Tenebrionidae): Influence of commodity and temperature. Journal of Stored Products Research 45: 165176.

Vishwamithra, V., Vijayalakshmi, K. and Reddy, K.L. 2014. Ecofriendly management of Callosobruchus chinensis L. in pigeonpea. Biolife 2(1): 341346. 